\title{
BIOLOGICAL TREATMENT CONJUGATED OF LANDFILL LEACHATE AND WASTEWATER
}

\author{
Gabriely D. D. Tavares $^{1 *}$, Evelyne M. F. Costa ${ }^{1}$, Jefferson S. de Amorim ${ }^{1}$ and \\ Valderi D. Leite ${ }^{2}$ \\ ${ }^{1}$ Sanitary and Environmental Engineering, State University of Paraíba, Brazil \\ ${ }^{2}$ Department of Sanitary and Environmental Engineering, State University of Paraíba, Brazil
}

Received 19 November 2020; received in revised form 15 October 2021; accepted 10 December2021

\begin{abstract}
Landfill leachate is a liquid waste with high concentrations of organic and inorganic matter, recalcitrant compounds, ammoniacal nitrogen, among other contaminants that can cause adverse effects on the environment. In view of its chemical characteristics, the leachate needs treatment before being launched into receiving bodies. Therefore, the objective of the present work was to evaluate the performance of a biological treatment system for landfill leachate plus domestic sewage, on a pilot scale, consisting of a UASB reactor, a percolator biological filter (PBF) and an anoxic reactor (AR). The substrate used to feed the UASB reactor consisted of a mixture of domestic sewage (97\%) plus landfill leachate (3\%). The mean efficiencies for the removal of total and filtered chemical oxygen demand, total suspended solids were, respectively, 82, 64 and $88 \%$. Low efficiency of removal of ammoniacal nitrogen was observed in the FBP, providing a reduction of $16 \%$. In the anoxic reactor, the denitrification process was observed, producing effluent with an average concentration of $0.42 \mathrm{mg} \cdot \mathrm{L}^{-1}$.
\end{abstract}

Keywords: Wastewater; biological treatment; nitrification; denitrification.

(C) 2021 Journal of Urban and Environmental Engineering (JUEE). All rights reserved.

* Correspondence to: Gabriely D. D. Tavares, Tel.: +55 8388642258.

E-mail: gabrielydias4@gmail.com 


\section{INTRODUCTION}

The economic development associated with population growth has directly influenced the generation of urban solid waste (USW), which requires proper disposal and treatment (Besen \& Fracalanza, 2016; Miao et al., 2019). Currently, the most appropriate technical option for the final destination of USW is the sanitary landfill (Aharoni et al., 2017; Han et al., 2016). However, this method of destination produces leachate from sanitary landfill, which is a liquid waste with complex chemical characteristics.

According to Sá et al. (2012), about 55\% (percentage by weight) of USW are made up of putrescible organic matter. When confined to a sanitary landfill and in the presence of a significant percentage of water and in a medium with no free molecular oxygen, the bioconversion process of this organic matter generates leachate from the sanitary landfill, a liquid residue that has high concentrations of ammoniacal nitrogen and recalcitrant organic matter, which tend to hinder the treatment of this effluent (El-Gohary \& Kamel, 2016; Bashir et al., 2013).

The inadequate management of leachate generated in landfills can cause negative environmental impacts, in order to compromise the availability and quality of natural resources. To protect the environment, the sanitary landfill leachate must be collected and treated properly, so that current regulations can be met before being released into bodies of water (Dia et al., 2018).

Several studies on the treatment of landfill leachate are being developed, however, due to the high cost and complexity to reach the launch standards, its treatment can be considered a great environmental challenge, being necessary the search for technologies that enable a viable treatment of this effluent. Methods based on biological processes have been widely used in the treatment of leachate because they are considered a simple and low cost treatment (Yong et al., 2018).

One of the alternatives for the treatment of leachate from landfills is the combined treatment with domestic sewage. The combination has been shown to be a good alternative, being investigated by several authors, who consider this a suitable solution for cities that have a Sewage Treatment Station (ETE) and that allows the ability to receive leachate contribution, without any negative interference in their performance regarding the efficiencies of removing carbonaceous material, nutrients and microorganisms. (Nascentes et al., 2016).

Experiments with UASB reactors, activated sludge, percolating biological filters, submerged aerated biofilter, stabilization ponds, physical and chemical processes, or a combination of these have been studied (Ferraz et al., 2014; Oliveira et al., 2015; Wu et al., 2019). In the combined biological treatment of landfill leachate and domestic sewage the association of anaerobic, aerobic and anoxic processes can provide greater efficiency in removing nitrogenous and carbonaceous material (Renou et al., 2008).

Anaerobic systems, such as UASB reactors, which are widespread in the treatment of domestic sewage can be applied in the treatment of leachate in order to remove carbonaceous organic matter (Abdelgadir et al., 2014). However, these processes do not allow efficient removal of nutrients, and percolating biological filters (PBF), in turn, can be used in the polishing of effluents from anaerobic reactors, removing nitrogen compounds through oxidation, in an aerobic environment, and can later be removed in another reactor that has an anoxic environment, through its reduction.

In this scenario, recent studies show that among the various processes available, the technologies that perform the combination of anaerobic, aerobic and anoxic processes have been shown to be a viable treatment option, presenting advantages in terms of economic and technical aspects, as these systems can promote the removal of carbonaceous material, nitrification and denitrification (Oliveira et al., 2015; Silva \& Leite, 2015; Leite et al., 2017).

In this perspective, the present work aims to analyze the performance of the process of combined treatment of landfill leachate and domestic sewage in a system consisting of anaerobic upflow sludge blanket (UASB), percolating biological filter (PBF) and anoxic reactor (AR), with an emphasis on biological removal of nitrogenous and carbonaceous material.

\section{MATERIALS AND METHODS}

The experimental work was carried out on the physical premises of the Estação Experimental de Tratamentos Biológicos de Esgotos Sanitários (EXTRABES) located in the Tambor district of Campina Grande $\left(7^{\circ} 13^{\prime} 11^{\prime \prime} \mathrm{S}\right.$, $35^{\circ} 52^{\prime} 31^{\prime \prime} \mathrm{W}$; altitude $550 \mathrm{~m}$ ).

The preparation of the substrate used in the feed of the UASB reactor consisted of the mixture of domestic sewage in the proportion of $97 \%$ with landfill leachate in the proportion of $3 \%$ (percentage by volume), being prepared daily the volume necessary for feeding the reactor. The definition of the proportion of leachate to be used in the treatment was obtained from the relation between the leachate flow rate produced at the landfill and the domestic sewage flow rate produced by the population of the city of Campina Grande.

The leachate used in this study was collected at regular four-month intervals at the landfill in the Metropolitan Region of the city of João Pessoa, capital of the state of Paraíba. After collection and storage, the leachate was transported to the physical facilities of the EXTRABES laboratory, and chemical characterization was then carried out. The domestic sewage used for the preparation of the substrate came from a residential building, located in the city of Campina Grande - PB, 50 meters from the land belonging to EXTRABES, 
being collected daily in a polyethylene box used in the storage of the domestic sewage generated in the housing unit.

The experimental system consisted of a reservoir for storing the substrate, an anaerobic upflow reactor and sludge blanket (UASB), a percolating biological filter (PBF) and an anoxic reactor (AR), being made with 150 $\mathrm{mm}$ PVC tubes, as shown in Fig. 1. The volume of the UASB reactor was $42 \mathrm{~L}$, usable height of $2.37 \mathrm{~m}$, and at the top a $150 \mathrm{~mm}$ PVC joint with a $100 \mathrm{~mm}$ reduction was installed, to which a $100 \mathrm{~mm}$ tube was formed forming the separator, UASB-Y configuration. The PBF had a unitary capacity of $35 \mathrm{~L}$, with $17 \mathrm{~L}$ filled by crushed stone $\mathrm{N}^{\mathrm{o}} 4$ (void index: 49\%) and a useful height of $1.80 \mathrm{~m}$. The volume of the anoxic reactor is $17.5 \mathrm{~L}$, with $15 \mathrm{~L}$ of the total volume filled by rigid PVC conduit (void index: $86.5 \%$ ) and usable height of $1.00 \mathrm{~m}$.

Figure 1 shows the scheme of the experimental system for the treatment of domestic sewage/landfill leachate during the monitoring period. The substrate was prepared and stored in a reservoir and piped to the UASB reactor using a metering pump (ProMinent $\AA$, modelo CNPB 1002). The substrate was evenly distributed at the bottom of the UASB reactor and in an upward manner came into contact with the sludge blanket. The effluent from the UASB reactor was stored in a reservoir with a capacity of $8 \mathrm{~L}$ and, by means of a pump, was distributed on the surface of the supporting material of the percolating biological filter, six times a day. The effluent (PBF) was stored and pumped by means of a metering pump (ProMinent $\mathbb{R}$, modelo CNPB 1002) for feeding the anoxic reactor.

The start of operation of the experimental system occurred after the inoculation of the UASB reactor with $8.4 \mathrm{~L}$ of sludge, $20 \%$ of the total volume of the reactor. The inoculum sludge came from an anaerobic reactor that treated domestic sewage and landfill leachate. In the UASB reactor, a volumetric organic load of 2.7 $\mathrm{kg} \cdot \mathrm{m}^{-3}$.day ${ }^{-1}$, volumetric hydraulic load of $3 \mathrm{~m}^{3} \cdot \mathrm{m}^{-3}$. day ${ }^{-1}$ and hydraulic detention time of $8 \mathrm{~h}$.

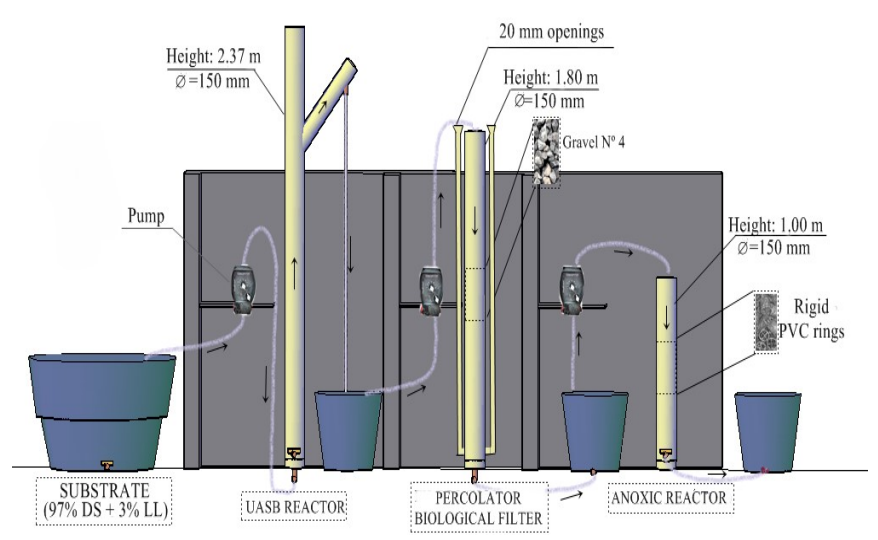

Fig. 1 Schematic representation of the experimental installations of the biological treatment system.
Table 1. Dimensions of the upflow anaerobic sludge blanket (UASB), percolating biological filter (PBF) and anoxic reactor (AR).

\begin{tabular}{cccc}
\hline & UASB & PBF & AR \\
\hline $\begin{array}{c}\text { Useful } \\
\text { height }(\mathrm{m})\end{array}$ & 2.37 & 1.80 & 1.0 \\
\hline Volume (L) & 42 & 35 & 17.5 \\
\hline Half support & - & Brita $^{\mathbf{0}}$ & PVC conduit \\
04 & 150 \\
\hline $\begin{array}{c}\text { Diameter } \\
(\mathrm{mm})\end{array}$ & 150 & 150 & 150 \\
\hline
\end{tabular}

The percolating biological filter was operated under unsaturated flow conditions, and the support medium is, therefore, permanently subject to the renewal of the air that naturally circulates in its empty spaces, providing the necessary oxygen for the respiration of the microorganisms. As shown in Fig. 1, the PBF had openings of $20 \mathrm{~mm}$ in diameter on the sides to favor the entry of air at the bottom of the PBF and to allow natural aeration of the medium. The feeding of the PBF with the effluent from the UASB reactor was carried out through a metering pump and a distributor with uniform orifices in the downward direction and occurred intermittently, with the duration of each cycle corresponding to $04 \mathrm{~h}$, totaling a quantity of six daily cycles. In the percolating biological filter, volumetric organic load of $1.2 \mathrm{~kg} \cdot \mathrm{m}^{-3}$. day ${ }^{-1}$, volumetric hydraulic load of $4.0 \mathrm{~m}^{3} \cdot \mathrm{m}^{-3} \cdot \mathrm{day}^{-1}$, surface application rate of 2.7 $\mathrm{m}^{3} \cdot \mathrm{m}^{-2}$.day ${ }^{-1}$ and affluent flow of $48 \mathrm{~L} \cdot \mathrm{day}^{-1}$.

In the anoxic reactor, the effluent flow was descending and the hydraulic detention time was 12 hours. The organic volumetric load applied to the reactor was $1.2 \mathrm{kgCOD} \cdot \mathrm{m}^{-3}$. $\mathrm{day}^{-1}$ and the volumetric hydraulic load of $4.0 \mathrm{~m}^{3} \cdot \mathrm{m}^{-3}$.day ${ }^{-1}$. Table 1 shows the physical parameters of each reactor that makes up the experimental system.

\section{Monitored parameters and analytical methods employed}

The monitored parameters were: $\mathrm{pH}$, alkalinity, volatile fatty acids (VFA), total and filtered chemical oxygen demand $\left(\mathrm{COD}_{\mathrm{T}}\right.$ and $\mathrm{COD}_{\mathrm{F}}$, respectively), total suspended solids (TSS), volatile suspended solids (VSS), total Kjeldahl nitrogen (TKN), ammoniacal nitrogen $\left(\mathrm{N}-\mathrm{NH}_{4}{ }^{+}\right)$, nitrate $\left(\mathrm{N}-\mathrm{NO}_{3}{ }^{-}\right)$, nitrite $\left(\mathrm{N}-\mathrm{NO}_{2}{ }^{-}\right)$, total phosphorus (PT) and orthophosphate $\left(\mathrm{P}_{-} \mathrm{PO}_{4}^{-3}\right)$, being analyzed according to the methodology recommended by the American Public Health Association (2012).

\section{RESULTS AND DISCUSSION}

\section{Chemical characterization of landfill leachate and domestic sewage}

Table 2 presents the parameter data from the chemical characterization of the landfill leachate (LL) and 
domestic sewage (DS) used in the preparation of the substrate.

Analyzing the data presented in Table 2, there are high concentrations of ammoniacal nitrogen in the landfill leachate, ranging from 2,320 to $2,570 \mathrm{mg} . \mathrm{L}^{-1}$. According to Lee et al. (2010), these high values are associated with the decomposition of organic matter and the hydrolysis of proteins present in the landfilled waste. Domestic sewage showed an average ammoniacal nitrogen concentration of $87.8 \mathrm{mg} . \mathrm{L}^{-1}$, a value much lower than that presented by LL, which allows the preparation of the substrate (97\% DS and 3\% LL) with adequate concentration for the development of microorganisms, enabling biological treatment, since ammoniacal nitrogen concentrations varying between 50 and $200 \mathrm{mg} . \mathrm{L}^{-1}$ do not interfere with the metabolic activity of microorganisms in anaerobic reactors (Shalini e Joseph, 2012).

The behavior of the hydrogen potential $(\mathrm{pH})$ did not show significant variations and is within the range presented in the literature for leachate with similar characteristics, presenting a tendency to a basic $\mathrm{pH}$ (Naveen et al., 2017; Dia et al., 2018; Xiao et al., 2013). According to Porowska (2015), after the first stages of oxidation of organic matter and due to the continued anaerobic degradation at the landfill, methanogenesis becomes the predominant phase. In this phase, there is a reduction in the levels of acetic acid and other organic acids generated previously, which causes an increase in the $\mathrm{pH}$ of the medium, justifying the results obtained in this work.

During the monitoring period, high concentrations of organic matter in terms of COD were observed throughout the leachate characterization. Based on the values found, the leachate can be classified as stabilized, regarding the $\mathrm{BOD}_{5} / \mathrm{COD}$ ratio (Silva et al., 2016). The values obtained in this relation indicate the biodegradability of this effluent.

Table 2. Data from chemical characterization of landfill leachate and domestic sewage.

\begin{tabular}{|c|c|c|}
\hline Parameters & $\mathrm{LL}$ & $\overline{\mathrm{DS}}$ \\
\hline$\overline{\mathrm{pH}}$ & 7.92 & 7.2 \\
\hline Alkalinity $\left(\mathrm{mg} \mathrm{CaCO}_{3} \cdot \mathrm{L}^{-1}\right)$ & $12339 \pm 2.5$ & $424 \pm 8.3$ \\
\hline $\operatorname{VFA}\left(m g \mathrm{H}_{\mathrm{AC}} \cdot \mathrm{L}^{-1}\right)$ & $2074 \pm 1151$ & $142 \pm 11.6$ \\
\hline $\mathrm{COD}_{\mathrm{T}}\left(\mathrm{mg} \cdot \mathrm{L}^{-1}\right)$ & $5701 \pm 1038$ & $641 \pm 7.7$ \\
\hline $\mathrm{COD}_{\mathrm{F}}\left(\mathrm{mg} \cdot \mathrm{L}^{-1}\right)$ & $2927 \pm 677.2$ & $310 \pm 6.6$ \\
\hline $\mathrm{BOD}_{5}$ & $1077 \pm 95.5$ & $347 \pm 7.3$ \\
\hline TSS (mg.L $\left.\mathrm{L}^{-1}\right)$ & $212 \pm 1$ & $360 \pm 11.6$ \\
\hline $\operatorname{VSS}\left(\mathrm{mg} \cdot \mathrm{L}^{-1}\right)$ & $169.6 \pm 23.6$ & $332 \pm 3.8$ \\
\hline TKN (mg.L $\left.\mathrm{L}^{-1}\right)$ & $2540 \pm 35$ & $103 \pm 1.7$ \\
\hline $\mathrm{N}-\mathrm{NH}_{4}{ }^{+}\left(\mathrm{mg} \cdot \mathrm{L}^{-1}\right)$ & $2360 \pm 146$ & $87.8 \pm 1.9$ \\
\hline $\mathrm{TP}\left(\mathrm{mg} \cdot \mathrm{L}^{-1}\right)$ & $17.5 \pm 0.5$ & $7.9 \pm 0.2$ \\
\hline $\mathrm{P}-\mathrm{PO}_{4}^{-3}\left(\mathrm{mg} \cdot \mathrm{L}^{-1}\right)$ & $8.8 \pm 4.2$ & $3.9 \pm 0.4$ \\
\hline
\end{tabular}

LL: Landfill leachate; DS: Domestic sewage; VFA: Volatile fatty acids; $\mathrm{COD}_{\mathrm{T}}$ : total chemical oxygen demand; $\mathrm{COD}_{\mathrm{F}}$ : filtered chemical oxygen demand; TSS: total suspended solids; VSS: volatile suspended solids; TKN: total Kjeldahl nitrogen
It was observed that this relation remained around 0.19 , which indicates a low degree of biodegradability, that is, it is a leachate from an old landfill, being confirmed, in fact, by the time of operation ASMJP, which has been operating since 2003, being approximately 17 years old (AMOR et al., 2015).

During the monitoring period, high concentrations of VFA were observed, one of the main contributors of COD in leachate (Budi et al., 2016). The average concentration of alkalinity was $12,339 \mathrm{mgCaCO} \cdot \mathrm{L}^{-1}$, values similar to that obtained in this study were also verified by Budi et al. (2016) and Naveen et al. (2017) when investigating leachate from landfills in Malaysia and India, respectively. High concentrations of alkalinity in leachate are associated with significant amounts of ammonium bicarbonate generated during the decomposition of organic material present in grounded USW (Mandal et al., 2017).

Table 3 shows the results obtained during the monitoring period of the experimental system. In Table 3 , the $\mathrm{pH}$ values remained stable, with small variations. These $\mathrm{pH}$ variations are acceptable, causing no inhibition of microbial activity (Lettinga et al., 1999). The anaerobic process provided an increase in $41 \mathrm{mg}$ $\mathrm{CaCO}_{3} \cdot \mathrm{L}^{-1}$, reaching average concentration of $774 \mathrm{mg}$ $\mathrm{CaCO}_{3} \cdot \mathrm{L}^{-1}$ in the effluent of the UASB reactor. This increase in the value of alkalinity is mainly due to the consumption of VFA and ammonification reactions, where the breakdown of nitrogenous organic compounds causes the release of ammonia and hydroxyl $\left(\mathrm{OH}^{-}\right)$(van Haandel \& van der Lubbe, 2012).

In the PBF (Table 3), the $\mathrm{pH}$ values were reduced due to the consumption of alkalinity, confirming the occurrence of the nitrification process. During the monitoring period there was a low consumption of alkalinity and low production of nitrate, theoretically, the nitrification process causes the consumption of 7.14 mg $\mathrm{CaCO}_{3}$ per mg of $\mathrm{N}^{-\mathrm{NH}_{4}}{ }^{+}$converted to $\mathrm{N}^{-\mathrm{NO}_{3}}{ }^{-}$ (van Haandel \& van der Lubbe, 2012). During this period there was an average consumption of total alkalinity of $153 \mathrm{mg} \mathrm{CaCO}_{3} \cdot \mathrm{L}^{-1}$, which theoretically corresponds to the oxidation of $21.5 \mathrm{mg} \mathrm{NH}_{4}^{+} \cdot \mathrm{L}^{-1}$. This performance may be associated with the low amount of oxygen present in the PBF and the low rate of nitrification. In the PBF effluent, a low reduction in total alkalinity is observed in the monitoring period, with an average concentration of $633 \mathrm{mg} \mathrm{CaCO}{ }_{3} \cdot \mathrm{L}^{-1}$.

In the anoxic reactor, the production of alkalinity is observed, and the parameters presented when compared to each other (effluent PBF and effluent AR) have the typical behavior of effluents that have gone through the denitrification process. The anoxic reactor showed production of $48 \mathrm{mg} \mathrm{CaCO}_{3} \cdot \mathrm{L}^{-1}$. The increase in alkalinity in the AR effluent indicates that the denitrification process and reduction of $\mathrm{NO}_{3}{ }^{-}$to $\mathrm{N}_{2}$. 
Table 3. Chemical characteristics (mean values \pm standard deviation) of the substrate and effluents from the experimental system

\begin{tabular}{|c|c|c|c|c|}
\hline PARAMETER & SUBSTRATE & UASB & PBF & $\mathrm{AR}$ \\
\hline $\mathrm{pH}$ & 7.6 & 7.74 & 7.57 & 7.63 \\
\hline Alkalinity $\left(\mathrm{mg} \mathrm{CaCO}_{3} \cdot \mathrm{L}^{-1}\right)$ & $733 \pm 13.3$ & $774 \pm 12.4$ & $632 \pm 48$ & $681 \pm 31.8$ \\
\hline $\operatorname{VFA}\left(\mathrm{mg} \mathrm{H}_{\mathrm{AC}} \cdot \mathrm{L}^{-1}\right)$ & $226 \pm 11.5$ & $87 \pm 7.6$ & $69 \pm 4.2$ & $63 \pm 3.9$ \\
\hline $\mathrm{COD}_{\mathrm{T}}\left(\mathrm{mg} \cdot \mathrm{L}^{-1}\right)$ & $933 \pm 25.3$ & $331 \pm 27$ & $226 \pm 21$ & $161 \pm 7.9$ \\
\hline $\mathrm{COD}_{\mathrm{F}}\left(\mathrm{mg} \cdot \mathrm{L}^{-1}\right)$ & $368 \pm 43$ & $218 \pm 55$ & $152 \pm 29$ & $130 \pm 12$ \\
\hline TSS $\left(\mathrm{mg} . \mathrm{L}^{-1}\right)$ & $457 \pm 33$ & $84 \pm 7.0$ & $67 \pm 6.9$ & $52 \pm 2.9$ \\
\hline $\operatorname{VSS}\left(\mathrm{mg} \mathrm{L}^{-1}\right)$ & $420 \pm 1.0$ & $69 \pm 6.5$ & $60 \pm 7.5$ & $47 \pm 2.4$ \\
\hline TKN (mg.L $\left.\mathrm{L}^{-1}\right)$ & $176 \pm 8.2$ & $174 \pm 5.8$ & $157 \pm 8.3$ & $140 \pm 11.5$ \\
\hline $\mathrm{N}-\mathrm{NH}_{4}{ }^{+}\left(\mathrm{mg} \cdot \mathrm{L}^{-1}\right)$ & $152 \pm 1.5$ & $165 \pm 3.1$ & $136 \pm 14.7$ & $138 \pm 12.8$ \\
\hline $\mathrm{N}-\mathrm{NO}_{2}^{-}$ & - & - & $21 \pm 13$ & $3.5 \pm 1.6$ \\
\hline $\mathrm{N}-\mathrm{NO}_{3}^{-}$ & - & - & $4 \pm 1.6$ & $0.4 \pm 0.08$ \\
\hline PT (mg.L $\left.{ }^{-1}\right)$ & $9.5 \pm 1.8$ & $8.9 \pm 0.9$ & $7.5 \pm 0.3$ & $7.3 \pm 0.7$ \\
\hline $\mathrm{P}-\mathrm{PO}_{4}^{-3}\left(\mathrm{mg} \cdot \mathrm{L}^{-1}\right)$ & $6.7 \pm 0.2$ & $6.6 \pm 0.5$ & $5.75 \pm 0.8$ & $5.5 \pm 1.1$ \\
\hline
\end{tabular}

UASB: upflow anaerobic sludge blanket; PBF: percolator biological filter; AR: anoxic reactor; VFA: volatile fatty acids; $\mathrm{COD}_{\mathrm{T}}$ : total chemical oxygen demand; $\mathrm{COD}_{\mathrm{F}}$ : filtered chemical oxygen demand; TSS: total suspended solids; VSS: volatile suspended solids; TKN: total Kjeldahl nitrogen.

The heterotrophic denitrification process causes the release of hydroxyl ions, consequently generating an increase in the alkalinity of the system, which can cause an increase in $\mathrm{pH}$. Analyzing the data obtained over the monitoring period, it can be seen that the average VFA concentration in the substrate was $226 \mathrm{mg} \mathrm{H}_{\mathrm{AC}} \cdot \mathrm{L}^{-1}$, ranging from 198 to $241 \mathrm{mg} \mathrm{H} \mathrm{HC}_{\mathrm{AC}} \cdot \mathrm{L}^{-1}$. The UASB reactor consumed $60 \% \mathrm{VFA}$, presenting an effluent with an average VFA concentration of $87 \mathrm{mg} \mathrm{H}_{\mathrm{AC}} \cdot \mathrm{L}^{-1}$. In the effluent from the UASB reactor, this decrease in VFA concentration is associated with the anaerobic process, in which the assimilation of volatile fatty acids occurs, carried out by bacteria and methanogenic archaea (van Haandel, 1994).

It is observed in the UASB reactor that the VFA/Alkalinity ratio was 0.09 . This value indicates that there was sufficient alkalinity in the system to neutralize the acids formed, buffering the medium and thus avoiding acidification of the reactor, which would compromise its performance. The VFA/Alkalinity ratio can be used as a measure of the stability of the anaerobic process (Raposo et al., 2009). According to Luque et al. (2013), when this ratio is greater than 0.3 it suggests the presence of disturbances in the digestion process.

In the FBP effluent, the average VFA concentration was $69 \mathrm{mg} \mathrm{H} \mathrm{H}_{\mathrm{AC}} \mathrm{L}^{-1}$. This decrease in VFA concentration in PBF is associated with the consumption of material organic by the microorganisms present.

In the anoxic reactor, a small reduction in VFA concentration was observed, producing effluent with an average concentration of $63 \mathrm{mg} \mathrm{H} \mathrm{H}_{\mathrm{AC}} \cdot \mathrm{L}^{-1}$. This reduction is related to the consumption of VFA by denitrifying microorganisms in the reduction of nitrate, which occurs in an anoxic environment.

Analyzing the data in Table 3, it is observed that the concentrations of $\mathrm{COD}_{\mathrm{T}}$ in the substrate varied in the range of 889 to $980 \mathrm{mg} . \mathrm{L}^{-1}$, reaching average concentration of $933 \mathrm{mg} . \mathrm{L}^{-1}$. In the effluent from the UASB reactor, the average total COD concentration was $331 \mathrm{mg} . \mathrm{L}^{-1}$, reaching average efficiency of removing $64 \%$. Behavior similar to that found in this study was found by Miorim (2017), obtaining a total COD removal of $63 \%$ when evaluating the combined treatment of LL (3\%) with domestic sewage in a UASB reactor. It is observed that the removal of organic matter in terms of total COD was more significant in the UASB reactor, the first stage of the process, with removal efficiencies above $60 \%$, corroborating with studies carried out by Oliveira et al. (2015); Miorim (2018); Araújo (2018). The PBF and AR effluents showed an average $\mathrm{COD}_{\mathrm{T}}$ concentration of 226 e 161 mg. $\mathrm{L}^{-1}$, respectively. It is observed that the combination of the UASB-PBF-AR system provided an $82 \%$ reduction in organic matter in terms of $\mathrm{COD}_{\mathrm{T}}$, a very significant result of removing carbonaceous material. The UASB reactor substrate and effluent showed an average $\mathrm{COD}_{\mathrm{F}}$ concentration of $368 \mathrm{mg} . \mathrm{L}^{-1}$ and 218 mg. $L^{-1}$, respectively. The UASB reactor provided removal efficiency of $41 \%$ of the $\mathrm{DQO}_{\mathrm{F}}$ present in the substrate. In PBF and AR effluents, $\mathrm{COD}_{\mathrm{F}}$ concentrations were 152 e $130 \mathrm{mg} . \mathrm{L}^{-1}$, respectively. The efficiency of removing $\mathrm{COD}_{\mathrm{F}}$ in the treatment system was $64 \%$.

Regarding the removal of solids, measured in terms of TSS and VSS, variations in concentrations in the effluent were observed throughout the monitoring period. As can be seen in Table 3, the average values of total and volatile suspended solids obtained in the substrate were 457 and $420.6 \mathrm{mg} . \mathrm{L}^{-1}$, respectively. In the effluent of the UASB reactor there is a significant reduction in suspended solids present in the substrate, with concentrations of $84.26 \mathrm{mg}$ TSS.L ${ }^{-1}$ and $69 \mathrm{mg}$ VSS.L $L^{-1}$, which demonstrates that the UASB reactor was able to significantly remove suspended solids, providing 
TSS and VSS removal efficiency of 82 and $84 \%$, respectively.

In the PBF and AR effluents, the average TSS concentrations were 67.6 and $52.7 \mathrm{mg} . \mathrm{L}^{-1}$, respectively. The combination of the three processes made it possible to remove TSS and VSS by $88 \%$. Ferraz et al. (2014), operating a submerged aerated biofilter $(2 \%$ LL and $98 \%$ DS), obtained similar results, achieving removal of $90 \%$ of total suspended solids.

Analyzing the data obtained during the monitoring of this experimental system (Table 3), it is observed that the concentrations of TKN in the substrate and in the effluents of the UASB, PBF and AR reactor were, respectively, 176, 174, 157 and $140 \mathrm{mg} . \mathrm{L}^{-1}$. In the substrate, it was found that organic nitrogen corresponded to $13.4 \%$, being mostly constituted by ammoniacal nitrogen $(86.6 \%)$. In the effluent from the UASB reactor, the TKN concentration remains constant, but a small fraction of organic nitrogen is converted to ammoniacal nitrogen through the ammonification process, and then approximately $8 \%$ of the nitrogenous organic fraction is converted, thus increasing the nitrogen concentration ammonia in the UASB effluent, corresponding to $95 \% \mathrm{NH}_{4}^{+}$and $5 \%$ organic nitrogen present in the effluent. In the effluent of the PBF there is a reduction in the concentration of $\mathrm{TKN}$, which is associated with the nitrification process, in which the oxidation of ammoniacal nitrogen to nitrite and nitrate occurs. The reduction in the concentration of ammoniacal nitrogen present in the UASB reactor occurs in the PBF, thus decreasing the concentration of TKN. Ammoniacal nitrogen $\left(21 \mathrm{mg} \cdot \mathrm{L}^{-1}\right)$ was oxidized, corresponding to a reduction of $13 \%$.

The average concentration of ammoniacal nitrogen in the substrate was $152.4 \mathrm{mg} \mathrm{N}-\mathrm{NH}_{4}{ }^{+} \cdot \mathrm{L}^{-1}$. In the effluent of the UASB reactor, there is an increase in the average concentration of ammoniacal nitrogen, which may result from the biological activity of hydrolysis and deamination of nitrogenous organic matter that occurred in the UASB reactor, the ammonification process. In this effluent, the average concentration was $165.3 \mathrm{mg}$ $\mathrm{N}-\mathrm{NH}_{4}{ }^{+} \cdot \mathrm{L}^{-1}$, with an $8 \%$ percentage increase in $\mathrm{N}_{-} \mathrm{NH}_{4}^{+}$ concentrations.

In the PBF effluent there are high concentrations of ammoniacal nitrogen, in which nitrification did not occur effectively and only a small part of $\mathrm{NH}_{4}^{+}$was converted to nitrite and nitrate, possibly due to the limitation of dissolved oxygen in the medium. The PBF provided an average removal efficiency of $16 \%$, producing effluent with a concentration of $136 \mathrm{mg} \mathrm{N}-$ $\mathrm{NH}_{4}^{+} \cdot \mathrm{L}^{-1}$. Despite the low $\mathrm{DO} / \mathrm{NH}_{4}^{+}$ratios, the nitrification process in the FBP occurred, which could be increased with greater oxygen supply to the environment, so that the conditions in the PBF could be optimized and an increase in specific biomass for the nitrification process. According to Gonçalves et al. (2001), for values in which the $\mathrm{DO}$ and $\mathrm{NH}_{4}{ }^{+}$ratio are very low, the aerobic compartment is dominated by heterotrophic bacteria and nitrification occurs very slowly.

Analyzing the data, it can be seen that the average concentrations of nitrite $\left(\mathrm{NO}_{2}^{-}\right)$and nitrate $\left(\mathrm{NO}_{3}{ }^{-}\right)$in the effluent of the percolating biological filter were 21 and $4 \mathrm{mg} . \mathrm{L}^{-1}$, respectively. The high concentration of nitrite and the low conversion to nitrate indicates that the percolating biological filter did not present satisfactory conditions in the oxidation process of ammoniacal nitrogen. Ammonia nitrogen concentrations are still high, requiring a greater amount of dissolved oxygen to promote and optimize the nitrification process (Zoppas et al., 2016). Another important factor, according to Yusof et al. (2010), is that ammoniacal nitrogen oxidizing bacteria can be inhibited by the nitrite ion and, in order for this inhibition not to occur, nitrite oxidizing bacteria must live in syntrophy with ammoniacal nitrogen oxidants. In addition, the $\mathrm{pH}$ must remain neutral to avoid the formation of nitrous acid during the process. Nitrous acid is one of the main responsible for the inhibition of oxidizing bacteria of ammonia and nitrite, and can also be the cause of low nitrification in the percolating biological filter.

The accumulation of nitrite in reactors with biofilm, such as PBF, is usually considered an indication that the rate of oxygen transfer or aeration is insufficient. As nitrite oxidizing bacteria have less affinity for oxygen, they require a higher transfer rate than ammoniacal nitrogen oxidators, being the first to be inhibited when it becomes deficient. Based on this premise, nitrite oxidizers would have reduced their activity and nitrite was predominant in the PBF effluent. Another possible argument is that the nitrite oxidizer population was not sufficient to convert the entire nitrite load produced, thus becoming the limiting factor for nitrification in the system (Yusof et al., 2010)

The introduction of oxygen through forced aeration provided a considerable increase in the production of nitrite and nitrate in some studies. Neto and Costa (2011) and Fulazzaky et al. (2015) reported that controlled aeration units have considerably increased the efficiency of nitrogen removal in biological treatment systems.

In the anoxic reactor, there was a reduction of nitrate present in the effluent in the percolating biological filter, reaching an average nitrate concentration of 0.42 mg. $\mathrm{L}^{-1}$. The amount of organic carbon in the medium was sufficient to promote the denitrification process, since the occurrence of this process is directly related to the amount of biodegradable organic matter present. In conventional biological treatments, the presence of easily biodegradable substrate is generally low, being removed in the previous steps, and for this reason, it is necessary to add an external carbon source to perform the denitrification process. 
The average concentrations of total phosphor in the substrate, effluent UASB, effluent PBF and effluent AR were: $9.47,8.53,7.56$ and 7.34 mg. $\mathrm{L}^{-1}$, respectively. It is also possible to notice a low phosphorus removal in the UASB reactor, reaching an efficiency of $9.8 \%$. The occurrence of this low removal is justified by the fact that anaerobic reactors do not have the objective of removing nutrients, but the removal of carbonaceous material by heterotrophic microorganisms. Nutrients can be removed in anaerobic systems through the processes of sedimentation and precipitation in the sludge, and by the assimilation of microorganisms. The total system showed a total phosphorus removal efficiency of $22 \%$. In a study carried out by Santos (2014), the average values of phosphorus removal efficiency obtained were similar, which obtained removal efficiency of $26 \%$.

The average concentration of orthophosphate in the tributary was $6.76 \mathrm{mg} . \mathrm{L}^{-1}$. In the effluent of the UASB reactor, the concentration was similar to that found in the substrate, with $6.6 \mathrm{mg} . \mathrm{L}^{-1}$ of orthophosphate. In the $\mathrm{PBF}$, there was a $10.2 \%$ reduction in the orthophosphate present in the UASB effluent, with an average concentration of $5.93 \mathrm{mg} . \mathrm{L}^{-1}$. In the effluent of the anoxic reactor the average concentration of orthophosphate was $5.57 \mathrm{mg} . \mathrm{L}^{-1}$.

\section{CONCLUSIONS}

Based on the results presented, it can be concluded that the combined treatment of landfill leachate and domestic sewage in the UASB reactor did not present significant interferences in the operational stability of the reactor. The efficiency of the UASB reactor was 64 and $63 \%$ of carbonaceous material in terms of total and filtered COD, respectively.

The combination of the anaerobic, aerobic and anoxic processes enabled a significant increase in the efficiency of removing carbonaceous material during the monitoring period. The treatment system provided removal efficiency of $82 \%$ of total COD and $88 \%$ of TSS and VSS.

The availability of alkalinity in the medium, throughout the experimental period, has always remained greater than the required quantity, providing favorable conditions for the nitrification and denitrification processes.

During the experiment, the PBF was naturally aerated and most of the ammoniacal nitrogen was converted to nitrite, resulting in partial nitrification of the medium, with ammoniacal nitrogen concentrations in the effluent still high. The low oxidation to nitrate is indicative of the lack of oxygen, because the nitrite oxidizing bacteria are more sensitive to DO variations, and to meet the oxygenation needs and improve the nitrification process, it would be necessary to add DO.

The average efficiency of removing ammoniacal nitrogen from the effluent was $16 \%$. The low concentration of dissolved oxygen in the PBF hampered the nitrification process during the first months of monitoring. In the anoxic reactor, the reduction of nitrate present in the effluent of the percolating biological filter was observed, producing final effluent with a concentration of $0.42 \mathrm{mg} \mathrm{NO} \mathrm{N}_{3}^{-} . \mathrm{L}^{-1}$. The results obtained confirmed the effective potential of polyethylene rings as an alternative support material in the biological treatment of effluents. In addition, its use allows cost reduction in the acquisition of the material, when compared to materials such as gravel, facilitates the maintenance and control of the biological treatment unit, due to its spatial conformation and constitution of the rings, and substantially reduces its mass per area occupied inside the anoxic reactor.

\section{REFERENCES}

Abdelgadir, A., Chen, X., Liu, J., Xie, X., Zhang, J., Zhang, K., Wang, H. \& Liu, N. (2014) Characteristics, process parameters, and inner components of anaerobic bioreactors. Biomed Research Internacional, v 2014, 10 p.

Aharoni, I., Siebner, H. \& Dahan, O. (2017) Application of vadosezone monitoring system for real-time characterization of leachate percolation in and under a municipal landfill. Waste Manag, 67, 203-213. doi: 10.1016/j.wasman.2017.05.012

Amor, C., Torres-Socías, E. De, Peres, J.A., Maldonado, M.I., Oller, I., Malato, S. \& Lucas, M.S. (2015) Mature landfill leachate treatment by coagulation/flocculation combined with Fenton and solar photo-Fenton processes. J. Hazard. Mater. doi: $\underline{\text { 10.1016/j.jhazmat.2014.12.036 }}$

APHA, A.A.P.H. (2012) Water Environment Federation (2012) Standard methods for the examination of water and wastewater. Washingt. DC, USA.

Araújo, E.C.O. (2018) Tratamento biológico conjugado de resíduos líquidos com ênfase na remoção de material orgânico e nitrogenado.

Bashir, M.J.K., Aziz, H.A., Aziz, S.Q. \& Abu Amr, S.S. (2013) An overview of electro-oxidation processes performance in stabilized landfill leachate treatment. Desalination and water treatment 51, 2170-2184.

Besen, G.R. \& Fracalanza, A.P. (2016) Challenges for the Sustainable Management of Municipal Solid Waste in Brazil. v.52, n.2, 45-52, doi: $\underline{\text { 10.1080/02513625.2016.1195583 }}$

Budi, S., Suliasih, B.A., Othman, M.S., Heng, L.Y. \& Surif, S. (2016) Toxicity identification evaluation of landfill leachate using fish, prawn and seed plant. Waste Manag. doi: $\underline{10.1016 / \text { j.wasman.2015.09.022 }}$

Dia, O., Drogui, P., Buelna, G. \& Dubé, R. (2018) Hybrid process, electrocoagulation-biofiltration for landfill leachate treatment. Waste Manag. doi: 10.1016/j.wasman.2018.02.016

El-Gohary, F.A. \& Kamel, G. (2016) Characterization and biological treatment of pre-treated landfill leachate. Ecological Engineering 94, 268-274.

Ferraz, F.M., Povinelli, J., Pozzi, E., Vieira, E.M. \& Trofino, J.C. (2014) Co-treatment of landfill leachate and domestic wastewater using a submerged aerobic biofilter. J. Environ. Manage. doi: $\underline{\text { 10.1016/j.jenvman.2014.03.022 }}$

Fulazzaky, M.A., Abdullah, N.H., Mohd Yusoff, A.R. \& Paul, E. (2015) Conditioning the alternating aerobic-anoxic process to enhance the removal of inorganic nitrogen pollution from a municipal wastewater in France. J. Clean. Prod. doi: 10.1016/j.jclepro.2015.03.043

Gonçalves, R.F., Chernicharo, C.A.D.L., Onofre, C., Além Sobrinho, P., Takayuki Kato, M., Costa, R.H.R. Da, Mansur, M. \& Zaiat, M. (2001) Pós-tratamento de efluentes de reactores 
anaeróbios por reatores com biofilme. Pós-tratamento efluentes React. anaerobios.

Han, Z., Ma, H., Shi, G., He, L., Wei, L. \& Shi, Q. (2016) A review of groundwater contamination near municipal solid waste landfill sites in China. Science of the Total Environ., 569-570, 1255-1264, doi: $10.1016 /$ j.scitotenv.2016.06.201

Lee, A.H., Nikraz, H. \& Hung, Y.T. (2010) Influence of Waste Age on Landfill Leachate Quality. Int. J. Environ. Sci. Dev. 347-350, doi: 10.7763 /ijesd.2010.v1.68

Leite, V.D., Oliveira, A.G. de, Campos, A.R.C., Sousa, J.T. de, Lopes, W.S. \& Oliveira, E.G. de (2017) Tratamento conjugado de lixiviado de aterro sanitário e esgoto doméstico em lagoas de estabilização. Rev. DAE doi: $10.4322 /$ dae.2016.036

Lettinga, G., Rebac, S., Parshina, S., Nozhevnikova, A., Van Lier, J.B. \& Stams, A.J.M. (1999) High-rate anaerobic treatment of wastewater at low temperatures. Appl. Environ. Microbiol. doi: $\underline{10.1128 / \text { aem.65.4.1696-1702.1999 }}$

Mandal, P., Dubey, B.K. \& Gupta, A.K. (2017) Review on landfill leachate treatment by electrochemical oxidation: Drawbacks, challenges and future scope. Waste Manag. 63, 250-273.

Miao, L., Wang, J. \& Zhang, P. (2019) Review on manganese dioxide for catalytic oxidation of airborne formaldehyde. Appl. Surf. Sci 466, 441-453.

Nascentes, A.L., Do Nascimento, M.M.P., Brasil, F.D.C., Campos, J.C. \& Ferreira, J.A. (2016) Tratamento combinado de lixiviado de aterro sanitário e esgoto doméstico - Aspectos operacionais e microbiológicos. Rev. Eletrônica TECCEN doi: 10.21727/teccen.v8i1.222

Naveen, B.P., Mahapatra, D.M., Sitharam, T.G., Sivapullaiah, P. V. \& Ramachandra, T. V. (2017) Physico-chemical and biological characterization of urban municipal landfill leachate. Environ. Pollution, 220, 1-12.

Neto, L.G.L. \& da Costa, R.H.R. (2011) Tratamento de esgoto sanitário em reator híbrido em bateladas sequenciais: Eficiência e estabilidade na remoção de matéria orgânica e nutrientes (N, P). Eng. Sanit. e Ambient..

Oliveira, E.G., Leite, V.D., Silva, R.B., Henrique, I.N. \& Barros, A.J.M. (2015). Tratamento anaeróbio e aeróbio de lixiviado de aterro sanitário. Rev. AIDIS 8, 360-371.

Porowska, D. (2015) Determination of the origin of dissolved inorganic carbon in groundwater around a reclaimed landfill in Otwock using stable carbon isotopes. Waste Manag.

Raposo, F., Borja, R., Martín, M.A., Martín, A., de la Rubia, M.A. \& Rincón, B. (2009) Influence of inoculum-substrate ratio on the anaerobic digestion of sunflower oil cake in batch mode: Process stability and kinetic evaluation. Chem. Eng. J. doi: 10.1016/j.cej.2008.10.001
Renou, S., Givaudan, J.G., Poulain, S., Dirassouyan, F. \& Moulin, P. (2008) Landfill leachate treatment: Review and opportunity. Journal of Hazardous Materials 150, 468-493.

Sá, L.F., Jucá, J.F.T. \& Motta Sobrinho, M.A. da (2012) Tratamento do lixiviado de aterro sanitário usando destilador solar. Ambient. e Agua - An Interdiscip. J. Appl. Sci. 204-217, doi: 10.4136/ambiagua. 815

Silva, R.B. da \& Leite, V.D. (2015) Tratamento conjugado de lixiviado de aterro sanitário e esgoto doméstico por processo anaeróbio seguido de aeróbio. Rev. DAE doi: $\underline{10.4322 / \text { dae. } 2014.143}$

Silva, T.F.C.V., Fonseca, A., Saraiva, I., Boaventura, R.A.R. \& Vilar, V.J.P. (2016) Scale-up and cost analysis of a photo-Fenton system for sanitary landfill leachate treatment. Chem. Eng. J. doi: $\underline{10.1016 / j . c e j .2015 .07 .063}$

Sri Shalini, S. \& Joseph, K. (2012) Nitrogen management in landfill leachate: Application of SHARON, ANAMMOX and combined SHARON-ANAMMOX process. Waste Manag. doi: 10.1016/j.wasman.2012.06.006

van Haandel, A.C. (1994) Influence of the digested COD concentration on the alkalinity requirement in anaerobic digesters. In: Water Science and Technology.

van Haandel, A.C. \& van der Lubbe (2012) Handbook of Biological Wastewater Treatment. Design and Optimization of Activated Sludge Systems. Internacional Water Association, London, 816p.

Wu, L., Li, Z., Huang, S., Shen, M., Yan, Z., Li, J. \& Peng, Y. (2019) Low energy treatment of landfill leachate using simultaneous partial nitrification and partial denitrification with anaerobic ammonia oxidation. Environ. Int.

Xiao, S., Peng, J., Song, Y., Zhang, D., Liu, R. \& Zeng, P. (2013) Degradation of biologically treated landfill leachate by using electrochemical process combined with UV irradiation. Sep. Purif. Technol. 24-29.

Yong, Z.J., Bashir, M.J.K., Ng, C.A., Sethupathi, S. \& Lim, J.W. (2018) A sequential treatment of intermediate tropical landfill leachate using a sequencing batch reactor (SBR) and coagulation. J. Environ. Manage.244-252.

Yusof, A.M., Keat, L.K., Ibrahim, Z., Majid, Z.A. \& Nizam, N.A. (2010) Kinetic and equilibrium studies of the removal of ammonium ions from aqueous solution by rice husk ashsynthesized zeolite $\mathrm{Y}$ and powdered and granulated forms of mordenite. J. Hazard. Mater.

Zoppas, F.M., Bernardes, A.M. \& Meneguzzi, Á. (2016) Parâmetros operacionais na remoção biológica de nitrogênio de águas por nitrificação e desnitrificação simultânea. Eng. Sanit. Amb, 29-42. 